the Christian subjects of the Sublime Porte were made amenable to the Turkish law.

Space does not permit me to treat of the history of the Ecloga in Eastern Europe at greater length. I can only refer the student to Dr. C. A. Spulber's recent work, in which he will find a text and a translation, in French, of the Ecloga, and a series of interesting and valuable chapters on the history of the Ecloga in the Balkan States and in Russia. (L'Eclogue des Isauriens. Texte Traduction, Histoire by C. A. Spulber, Professeur à l'université de Cernautzi. Published at Cernautzi by the Librairie Muhldorf in 1929). The atudent should also consult the Compte Rendu by Professors D. Mastasijevic and $\mathrm{Ph}$. Granic of the proceedings at the International Congress held at Belgrade in 1927 to promote the study of Byzantine history.

\title{
In SISemoriam.
}

\section{Professor COURTNEY STANHOPE KENNY, F.B.A., LL.D.}

IT is fitting that we should pay a tribute to the memory of a brilliant teacher and writer who had been associated with the Law Faculty of Cambridge for more than half a century. Probably none of the present generation of undergraduates ever heard Dr. Kenny lecture, for he retired from the Downing Professorship of the Laws of England in 1918, and though he subsequently delivered a course for an absent friend, that was some years ago. But some idea of his unsurpassed ability as a lecturer can be grasped by those who, in their College Law Societies, have heard Dr. Kenny read such fascinating accounts of trials as he used to give-especially those connected with the Tichborne claimant. And every candidate for Part $I$ of the Law Tripos must have read his incomparable Outlines of Criminal Law. It stands in high relief against the pedestrian dullness with which this dramatic topic has usually been treated by writers. A signal mark of the high estimation in which it stands is its use in other countries as well as our own. It has been adapted to the needs of American students, and has been translated into Japanese among other languages. Besides writing roviews for the Cambridge Law Journal, Dr. Kenny contributed two admirable articles on the position of the British Self-governing Dominions. 